\title{
Off-pump coronary artery bypass surgery in left main coronary artery disease: the last frontier?
}

Revascularização miocárdica sem circulação extracorpórea em lesão de tronco da artéria coronária esquerda: a última fronteira?

João C. LEAL ${ }^{1}$, Moacir F. GODOY ${ }^{1}$, Domingo M. BRAILE' ${ }^{1}$ Enio BUFFOLO²

RBCCV 44205-627

Abstract

Objective: Our aim is to demonstrate the possibility of applying the alternative tactic of off-pump coronary artery bypass surgery to left main coronary artery disease and to assess the long-term results over a 5-year follow-up period.

Methods: Among 210 subjects submitted to off-pump coronary artery bypass, $119(56.7 \%)$ were male. Their ages ranged from 32 to 81 years with a mean age of 59.7. A left coronary artery branch lesion of at least $70 \%$ was demonstrated in $48(22.8 \%)$ of the individuals and a right coronary lesion was associated in $10(\mathbf{2 0 . 8 \%})$ of the cases.

Results: A breakdown of the number of grafts per patient was: 2 for $52.1 \%, 3$ for $43.5 \%$ and 4 for $4.4 \%$ of the surgeries. All of the patients were extubated in the intensive care unit after a 6-hour stay. No left ventricular dysfunction was evidenced after a seven-day total hospitalization period. One death, due to cardiac problems, occurred after one month. Follow-up with clinical cardiac evaluation was total until 60 months with a survival rate at 5 years of $96.0 \% \pm 3.9 \%$.

Conclusion: In left main coronary artery disease, which is feared by cardiac surgeons, we believe that the technique of off-pump coronary artery bypass could be very useful. If the patients are hemodynamically stable and undergo an elective operation, the operative period can be passed in a safe and tranquil manner.

Descriptors: Myocardial revascularization. Coronary disease. Left main coronary artery.

Resumo

Objetivo: Demonstrar a possibilidade de aplicar alternativa técnica e tática operatória na lesão do tronco da artéria coronária esquerda com avaliação dos resultados tardios, aos cinco anos de observação.

Método: Entre julho de 1998 a março de 2002, 210 pacientes foram submetidos a revascularização miocárdica sem circulação extracorpórea (CEC), sendo 119 (56,7\%) do gênero masculino. As idades variaram entre 32 e 81 anos, com média de 59,7 anos e desvio padrão de $\mathbf{1 0 , 5}$ anos. A lesão no tronco da artéria coronária esquerda esteve presente em $48(22,8 \%)$ pacientes, levando em conta graus de lesões acima de $70 \%$ e a lesão em artéria coronária direita esteve associada em 10

\footnotetext{
- Medical School, São José do Rio Preto - FAMERP.

2 - Federal University, São Paulo - UNIFESP, SP, Brazil

Correspondence address: João C. Leal. Braile Cardiocirurgia. Rua: Luis de Camões 3111. São José do Rio Preto, SP, Brazil. CEP $15015-450$

*Work presented at the National Congress of Cardiac Surgery, Goiânia, $5^{\text {th }}$ April 2003.
} 
$(20,8 \%)$ casos. Todos pacientes apresentavam fração de ejeção acima de $\mathbf{4 0} \%$ no ecocardiograma pré-operatório.

Resultados: A estratificação do número de enxertos por paciente foi: 2 enxertos $(52,1 \%) ; 3$ enxertos $(43,5 \%)$ e 4 enxertos $(4,4 \%)$. Não ocorreu infarto agudo do miocárdo perioperatório, fibrilacão ventricular ou óbito no transoperat (a)eratorio. cardiológica, ocorreu apenas 1 óbito de causa cardíaca após 1 mês de seguimento. A taxa sobrevivência aos 5 anos de

\section{INTRODUCTION}

At the start of the 1980s, new alternatives appeared for the surgical treatment of coronary disease patients with single and multiple artery involvement. Off-pump coronary artery bypass grafting, denominated as OPCAB, started in two independent South American centers, in Brazil with BUFFOLO et al. [1] and in Argentina with BENETTI [2]. After encouraging results in expressive series, the technique progressively spread both here and abroad as a safe and reproducible technique.

The off-pump left anterior small thoracotomy (LAST) also started to be utilized [3]. Historically, it is good to remember that already in 1967 KOLESSOV [4] in Russia, performed the first off-pump left anterior thoracotomy with anastomosis of the left internal thoracic artery (LITA) to the anterior interventricular branch (AIB) and the marginal branch of the left coronary artery in a pregnant woman. Videothoracoscopy developed for use with the thorax closed was introduced for the dissection of the LITA, and in Brazil the technique gave good results, as reported by NATAF et al. [5] and JATENE et al. [6] with a restriction being its high cost.

It is known that surgical correction of a lesion of the branch of the left coronary artery is feared by heart surgeons due to its anatomic location and possible repercussions that can result from technical or tactica errors. The causes of hemodynamic instability during cardiopulmonary bypass (CPB) are ischemia, mechanical or a combination of the two [7]. In patients with lesions of the left coronary artery branch, the tolerance of cardiac manipulation associated with $\mathrm{OPCAB}$ is a limiting factor for the application of this technique.

The objective of this study is to demonstrate the possibility of applying this alternative tactic to lesions of the left coronary artery branch and to evaluate the long-term results over a five-year follow up period. seguimento foi de $96,0 \pm 3,9 \%$.

Conclusões: Nas lesões do tronco da artéria coronária esquerda, temidas pelos cirurgiões cardíacos, acreditamos que a técnica e a tática sem uso da CEC podem ser úteis, uma vez que os pacientes estejam com estabilidade hemodinâmica.

Descritores: Revascularização miocárdica. Coronariopatia. Lesão de tronco coronariano esquerdo.

\section{METHOD}

Between July 1998 and March 2002, 210 patients, 119 (56.7\%) of whom were male, were submitted to off-pump coronary artery bypass grafting (OPCAB). The ages ranged from 32 to 81 years with a mean of 59.7 years and a standard deviation of 10.5 years.

Lesions of the left coronary artery branch were presen in $48(22.8 \%)$ patients, when considering degrees of greater than $70 \%$ and lesions of the right coronary artery was associated in $10(20.8 \%)$ of the cases. All the patients presented with ejection fractions of greater than $40 \%$ in the pre-operative echocardiogram.

The operative procedures were elective and without previous acute myocardial infarction. The patients underwen median sternotomy in the conventional position, the pericardium was opened and the coronary arteries to be grafted were evaluated in relation to their operative conditions (if intramyocardial, calcified and/or with diameters less than 1.5 $\mathrm{mm}$ ). Devices and operational tactics were used to optimize the technique such as coronary intraluminal perfusors, compression stabilizer, flow puffers of oxygen and water, Lima Bridge, right pleura opening, rotation of the operating table and vasodilators allowed anastomoses of the posterior coronary arteries in a safe manner and more tranquility for the surgeon, even with the beating heart [8-11].

The Research Commission of Braile Cardiocirurgia approved this study.

\section{RESULTS}

The grafts employed were the LITA, radial artery and saphenous vein. Stratification of the grafts per patient was as follows: two grafts $52.1 \%$; three grafts $43.5 \%$ and four grafts $4.4 \%$. Acute myocardial infarction, ventricular fibrillation or death did not occur during the operative procedures. All the patients were released from the intensive care unit after 36 hours. Blood derivatives were used in only 
four $(8.3 \%)$ procedures. Electrocardiographic alterations, elevations in the serum enzymes and left ventricular dysfunction were not evidenced by echocardiography up to 7 days after hospitalization.

Follow up was achieved with all the patients until 60 months with clinical evaluation and only one death occurred due to acute myocardial infarction after one month of follow up. The survival rate at five years was $96.0 \pm 3.9 \%$ (Figure 1)

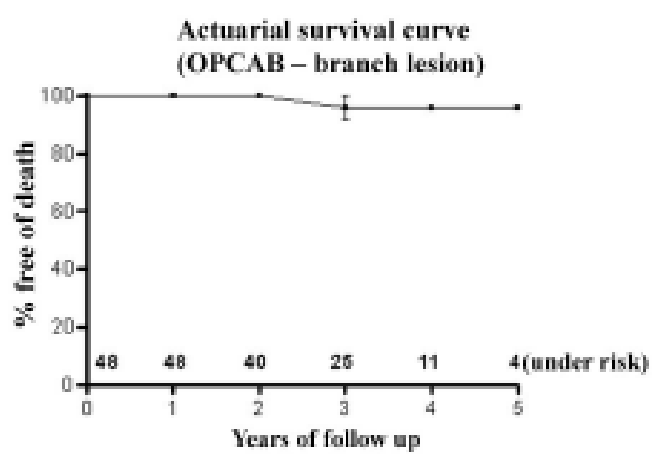

Fig. 1 - Actuarial survival curve showing follow up of 60 months

\section{COMMENTS}

The evidence demonstrates the benefits of OPCAB by presenting positive results in publications. The smallest reduction in blood transfusions during the operative procedure contributes to a reduction in the post-operative complications. The quicker endotracheal extubation, the shorter hospital stay and the lower hospital infection all diminish the cost of the procedures [12-14].

Vasoplegic syndrome (VS), a frequent complication in heart surgery, consequent to the systemic inflammatory response is attributed to the use of $\mathrm{CPB}$. The growing enthusiasm for OPCAB is due to the absence of $\mathrm{CPB}$ avoiding the deleterious effects which include retention of volume, coagulopathies, pulmonary dysfunction, stroke and the signs and symptoms of inflammatory response such as systemic arterial hypotension, tachycardia, hyperthermia with normal or increased heart outflow [15-17].

Patients submitted to coronary artery bypass grafting however develop VS. Nevertheless, by avoiding CPB the incidence of VS was $0.4 \%$ in a cohort of 1014 patients [18].

The Coronary Artery Surgery Study (CASS) [19] and the Veteran's Administration Cooperative Study (VACS) [20] demonstrated that coronary artery bypass grafting in patients with lesions of the left coronary artery branch obtained a greater survival rate. MEHARWAL et al. [21] obtained promising results with OPCAB in high-risk patients with multiple arterial coronary disease. A retrospective comparative study demonstrated that the mortality until 30 days was $1 \%$ with an $\mathrm{OPCAB}$ group and $4.7 \%$ with a $\mathrm{CPB}$ group in patients from a left coronary artery branch lesion subgroup [22]

In our study of patients with lesions of the left coronary artery branch presenting with hemodynamic stability and undergoing elective surgery, OPCAB was demonstrated as a safe and effective alternative for patients without previous acute myocardial infarction and with ejection fraction values above $40 \%$. The evaluation of the caliber of the coronary arteries and the use of support techniques in OPCAB are important for the optimization of the operative technique.

OPCAB continues to be a technique under development and the learning curve is of extreme importance in the reproduction of results, giving safety and efficacy to the procedure.

\section{BIBLIOGRAPHIC REFERENCES}

1. Buffolo E, Andrade JC, Succi JE, Leão LE, Cueva C, Branco $\mathrm{JN}$ et al. Revascularização direta do miocárdio sem circulação extracorpórea: descrição da técnica e resultados iniciais. Arq Bras Cardiol 1982; 38:365-73.

2. Benetti FJ. Cirurgia coronaria directa com bypass de vena safena sin circulación extracorpórea o parada cardíaca: comunicación previa. Rev Fed Arg Cardiol 1980; 8: 3.

3. Calafiore AM, Giammarco GD, Teodori G. Bosco G, D'Annunzio E, Barsotti A et al. Left anterior descending coronary artery grafting via left anterior small thoracotomy without cardiopulmonary bypass. Ann Thorac Surg 1996; 61: 1658-65.

4. Kolessov VI. Mammary artery-coronary artery anastomosis as method of treatment for angina pectoris. J Thorac Cardiovasc Surg 1967; 54: 535-44.

5. Nataf P, Lima L, Regan M, Benarim S, Pavie A, Cabrol C et al. Minimally invasive coronary surgery with thoracoscopic internal mammary artery dissection: surgical technique. J Card Surg 1996; 11: 288-92.

6. Jatene FB, Pêgo-Fernandes PM, Hayata ALS, Arbulu HE, Stolf NA, Oliveira SA et al. VATS for complete dissection of LIMA in minimally invasive coronary artery bypass grafting. Ann Thorac Surg 1997; 63: S110-3.

7. Vassiliades Jr. TA, Nielsen JL, Lonquist JL. Hemodynamic collapse during off-pump coronary artery bypass grafting. Ann Thorac Surg 2002; 73:1874-9. 
8. Rivetti LA, Gandra SM. Initial experience using an intralumina shunt during revascularization of the beating heart. Ann Thorac Surg 1997; 63: 1742-7.

9. Shennib H, Lee AG, Akin J. Safe and effective method of stabilization for coronary artery bypass grafting on the beating heart. Ann Thorac Surg 1997; 63: 988-92.

10. Jansen EWL, Grundeman PF, Beck HJM, Heijmen RH, Borst C. Experimental off-pump grafting of a circunflex branch via sternotomy using a suction device. Ann Thorac Surg 1997; 63(suppl.): S93-6.

11. Lima RC. Surgical techniques of coronary artery exposure. In: Beating heart coronary artery surgery. 1ed. New York Futura Publishing Company; 2001. p. 21-34.

12. Lobo Filho JG Leitão MC, Oliveira FM, Siqueira FM, Siqueira R, Oliveira RR, Landim R. Total myocardial revascularization without cardiopulmonary bypass: a reality. Heart Surg Forum 2002; 5: 173-6.

13. Lee JH, Kim KH, van Heeckeren DW, Murrell HK, Cmolik $\mathrm{BL}$, Graber R et al. Cost analysis of early extubation after coronary bypass surgery. Surgery 1996; 120: 453-62.

14. Lucchetti V; Caputo M; Suleiman MS, Capece M, Brando G, Angelini GD et al. Beating heart coronary revascularization without metabolic myocardial damage. Eur J Cardiothorac Surg $1998 ; 14 \cdot 443-4$

15. Gu YJ, Mariani MA, van Oeveren W, Grandjean JG, Boonstra PW et al. Reduction of inflammatory response in patients undergoing minimally invasive coronary artery bypass grafting. Ann Thorac Surg 1998, 65:420-4.
16. Buffolo E, Andrade JC, Branco JN, Teles CA, Aguiar LF, Gomes WJ. Coronary artery bypass grafting without cardiopulmonary bypass. Ann Thorac Surg 1996; 61:63-6.

17. Gomes WJ, Erlichman MR, Batista-Filho ML, Knobel M, Almeida DR, Carvalho AC et al. Vasoplegic syndrome after off-pump coronary artery bypass surgery. Eur J Cardiothorac Surg 2003; 23:165-9.

18. Diegeler A, Tarnor A, Rauch T, Haberer D, Falk V, Battelini R et al. Changes of leukocyte subsets in coronary artery bypass surgery: cardiopulmonary bypass versus off-pump techniques. Thorac Cardiovasc Surg 1998; 46:327-32.

19. Caracciolo EA, Davis KB, Sopko G, Kaiser GC, Corley SD, Schaff $\mathrm{H}$ et al. Comparison of surgical and medical group survival in patients with left main equivalent coronary artery bypass disease: long term CASS experience. Circulation 1995; 91:2325-44.

20. Veterans Administration Coronary Artery Bypass Surgery Cooperative Study Group. Eleven year survival in the Veterans Administration Randomized Trial of Coronary Bypass Surgery for stable angina. N Engl J Med 1984; 311:133-9.

21. Meharwal ZS, Mishra YK, Kohli V, Bapna R, Singh S, Trehan N. Off-pump multivessel coronary artery surgery in high-risk patients. Ann Thorac Surg 2002; 74: S1353-7.

22. Dewey TM, Magee MJ, Edgerton JR, Mathison M, Tennison D, Mack MJ. Off-pump bypass grafting is safe in patient with left main coronary disease. Ann Thorac Surg 2001; 72:788-92. 